\title{
A novel Aaproach to increase cell wall saccharification for efficient biofuel production
}

\author{
Miron Abramson ${ }^{*}$, Oded Shoseyov ${ }^{2}$, Ziv Shani ${ }^{3}$ \\ From IUFRO Tree Biotechnology Conference 2011: From Genomes to Integration and Delivery \\ Arraial d Ajuda, Bahia, Brazil. 26 June - 2 July 2011
}

The conversion of biomass to biofuels requires heat, pressure and acid treatments to overcome the recalcitrance of the cell wall and remove lignin that hinders access to cellulose. Economic production of biofuels from lignocellulosic biomass and efficient sugar release depends on the ability to reverse and overcome this natural recalcitrance of the plant cell wall.

Most of the current ideas and methods to generate lignocellulose feedstock which is more amenable to saccharification, are limited to the modification or downregulation of the lignin biosynthesis. This often results in dwarfing, xylem vessel collapse or reduced fitness to stress. In order to overcome these limitations, we present here a novel approach for cell wall remodeling. By introducing new trans-genes from algae, fungi and viruses we create "Trojan Horses": polymer pockets of enhanced solubility within the cell wall, thus increasing cellulose accessibility to solvents and enzymes. Two different methodologies are presented. The first includes transgenic introduction of soluble polysaccharides such as hyaluronan into the cell wall during its development, leading to its intercalation with the cellulose microfibrils. Upon processing, these soluble intercalated polysaccharides are washed away, resulting in highly porous cell walls with increased accessibility to hydrolytic enzymes. The second methodology involves modification of the cellulose by expression of recombinant cellobiose dehydrogenase (CDH) in plant cell walls, leading to disruption of the cellulose microcrystalline lattice and thus increasing hydrolytic enzymes accessibility. Both methodologies result in transgenic plants that exhibit significantly enhanced cellulose hydrolysis, while maintaining their physiological and structural integrity.

\footnotetext{
* Correspondence: miron@futuragene.com

${ }^{1}$ The Robert H. Smith Institute of Plant Sciences and Genetics in Agriculture, Rehovot, Israel; Futuragene Ltd., Rehovot, Israel

Full list of author information is available at the end of the article
}

This novel concept provides new prospects for more economical production of liquid biofuel to substitute fossil fuels.

\section{Author details \\ ${ }^{1}$ The Robert H. Smith Institute of Plant Sciences and Genetics in Agriculture, Rehovot, Israel; Futuragene Ltd., Rehovot, Israel. ${ }^{2}$ The Robert H. Smith Institute of Plant Sciences and Genetics in Agriculture, Rehovot, Israel. ${ }^{3}$ Futuragene Ltd., Rehovot, Israel.}

Published: 13 September 2011

doi:10.1186/1753-6561-5-S7-P104

Cite this article as: Abramson et al:: A novel Aaproach to increase cell wall saccharification for efficient biofuel production. BMC Proceedings 2011 5(Suppl 7):P104.

Submit your next manuscript to BioMed Central and take full advantage of:

- Convenient online submission

- Thorough peer review

- No space constraints or color figure charges

- Immediate publication on acceptance

- Inclusion in PubMed, CAS, Scopus and Google Scholar

- Research which is freely available for redistribution

Submit your manuscript at www.biomedcentral.com/submit
( Biomed Central 